28 Tollefsen IM, Hem E, Ekeberg O. The reliability of suicide statistics: a systematic review. BMC Psychiatry 2012; 12: 9.

29 Guth U, Myrick ME, Reisch T, Bosshard G, Schmid SM. Suicide in breast cancer patients: an individual-centered approach provides insight beyond epidemiology. Acta Oncol 2011; 50: 1037-44.

30 Fischer S, Huber CA, Furter M, Imhof L, Mahrer IR, Schwarzenegger C, et al. Reasons why people in Switzerland seek assisted suicide: the view of patients and physicians. Swiss Med Wkly 2009; 139: 333-8.

31 Lorant V, Kunst AE, Huisman M, Costa G, Mackenbach J. Socio-economic inequalities in suicide: a European comparative study. Br J Psychiatry 2005; 187: 49-54.

32 Stravynski A, Boyer R. Loneliness in relation to suicide ideation and parasuicide: a population-wide study. Suicide Life Threat Behav 2001; 31 32-40.
33 Guo Q, Jacelon CS. An integrative review of dignity in end-of-life care. Palliat Med 2014; 28: 931-40.

34 Panczak R, Spoerri A, Zwahlen M, Bopp M, Gutzwiller F, Egger M. Religion and suicide in patients with mental illness or cancer. Suicide Life Threat Behav 2013; 43: 213-22.

35 Canetto SS, Sakinofsky I. The gender paradox in suicide. Suicide Life Threat Behav 1998; 28: 1-23.

36 Gamondi C, Pott M, Forbes K, Payne S. Exploring the experiences of bereaved families involved in assisted suicide in Southern Switzerland: a qualitative study. BMJ Support Palliat Care 2015; 5: 146-52.

\title{
Lovely young consultant charms my husband
}

\section{poems by doctors}

\section{Kate Compston}

'Look! here and here,' she breathes. I note

her intentness, as the three

of us pore over her strange map.

I see his greying face

light at her nearness, how he floats in her interest in him. I could be

half in love with her myself, lap

at her kindness greedily, but brace

myself to hear her verdict. Poet

in an alien tongue and territory, she

rhapsodizes about gaps

where gaps ought not to be. 'We trace

low dopamine uptake....' (she strokes her throat,

addressing me): 'Dementia - DLB.

Given the other signs - the overlap

of dream and real, the slowing pace,

visual hallucinations, remote

expression - this scan wraps

up my diagnosis ...'

(stops and holds his hand, devotes

herself to him): 'Together, we

will deal with this thing, yes?

Embraced

by her concern, he throws aside

encroaching night, flings his windows wide.

The trap door of my heart slams shut.

From The Hippocrates Prize 2015: The Winning and Commended Poems, selected by T Dalrymple, R Gross, F Oyebode and S Rae, eds MW Hulse \& DRJ Singer. The Hippocrates Press, 2015. (c) Kate Compston. Reprinted with permission. Kate worked in the NHS as a BACP Senior Counsellor and is now retired. 